\title{
Penyuluhan Tentang Imunisasi Dasar, Vitamin A dan Tumbuh Kembang pada Bayi dan Balita di Wilayah Puskesmas Jenggot Kota Pekalongan
}

\author{
Putri Andanawarih ${ }^{1}$, Miftachul Jannah ${ }^{2}$ \\ Email : poetry_andana@yahoo.com \\ DIII AKBID Harapan Ibu Pekalongan \\ Jl. Sriwijaya No 7 Pekalongan \\ Telp/Fax (0285) 4416108
}

\begin{abstract}
Abstrak
Mendukung dan mempertahankan pengawasan program imunisasi dan pemberian Vitamin A di Indonesia merupakan salah satu usaha dalam menurunkan AKI dan AKB. Imunisasi adalah salah satu intervensi kesehatan masyarakat yang paling efektif dalam upaya mencegah morbiditas dan mortalitas. Vitamin A merupakan salah satu gizi penting yang larut dalam lemak dan disimpan dalam hati, tidak dapat dibuat oleh tubuh, sehingga harus dipenuhi dari luar (essensial), berfungsi untuk penglihatan, pertumbuhan dan meningkatkan daya tahan tubuh terhadap penyakit. Vitamin A bermanfaat untuk menurunkan angka kematian dan angka kesakitan, karena itu vitamin A dapat meningkatkan daya tahan tubuh terhadap penyakit infeksi seperti campak, diare, dan ISPA. Akibat lain yang berdampak sangat serius dari KVA adalah buta senja dan manifestasi lain dari xeropthalmia termasuk kerusakan kornea dan kebutaan, tim melakukan pegabdian masyarakat dengan judul "Penyuluhan Tentang Imunisasi Dasar,Vitamin A dan Tumbuh Kembang pada Bayi dan Balita di Wilayah Puskesmas Jenggot Kota Pekalongan" dengan metode Penyuluhan program imunisasi dasar pada bayi dan balita, pemberian vitamin A dan pemantauan pertumbuhan dan perkembangan anak, hasil dari Pengabdian kepada masyarakat tersebut yaitu berhasil meningkatkan pengetahuan ibu tentang imunisasi dasar dan vitamin A. Hasil evaluasi kegiatan pada hasil post test sebanyak $35 \%$ pada pengetahuan tentang imunisasi dan $48 \%$ pada pengetahuan vitamin A.
\end{abstract}

Kata Kunci : Imunisasi dasar, Vitamin A, Tumbuh Kembang, Bayi dan Balita.

\begin{abstract}
Supporting and maintaining surveillance of immunization programs and provision of Vitamin A in Indonesia is one of the efforts in reducing MMR and IMR. Immunization is one of the most effective public health interventions in preventing morbidity and mortality. Vitamin A is one of the important nutrients that is fat soluble and stored in the liver, cannot be produced by the body, so it must be fulfilled from the outside (essential), functioning to vision, growth and increase the body's resistance to disease. Vitamin A is useful for reducing mortality and morbidity, because of that vitamin A can increase the body's resistance to infectious diseases such as measles, diarrhea, and Acute Respiration Infection (ISPA). Other consequences that have a very serious impact from Vitamin A Deficiency (KVA) are night blindness and other manifestations of xeropthalmia including corneal damage and blindness. The team conducted community service under the title "Counseling about Basic Immunization, Vitamin A and Growth in Infants and Toddlers in the Jenggot Public Health Center-Pekalongan ". The methods of counseling basic immunization programs for infants and toddlers, providing vitamin $\mathrm{A}$ and monitoring the growth and development of children. The results of the evaluation of activities on the post test results were $35 \%$ on knowledge about immunization and $48 \%$ on knowledge of vitamin A.
\end{abstract}

Keywords: Immunization, Vitamin A, Growth and Development, Infants and Toddlers. 


\section{Pendahuluan}

Angka kematian bayi dan balita yang tinggi di Indonesia menyebabkan turunnya derajat kesehatan masyarakat. Masalah ini mencerminkan perlunya keikutsertaan Pemerintah di tingkat nasional untuk untuk mendukung dan mempertahankan pengawasan program imunisasi dan pemberian Vitamin A di Indonesia ${ }^{(1)}$.

Untuk terus menekan angka kematian bayi dan balita, program imunisasi dan Pemberian Vitamin A terus digalakkan Pemerintah Indonesia. Namun, ternyata program ini masih mengalami hambatan, yaitu penolakan dari orang tua. Penolakan orang tua dalam pemberian imunisasi dan pemberian vitamin A ini dikarenakan anggapan yang salah yang berkembang di masyarakat tentang dampak imunisasi dan pemberian vitamin A, tingkat pengetahuan yang rendah, dan kesadaran yang kurang terhadap imunisasi $^{(2)}$.

Imunisasi adalah salah satu intervensi kesehatan masyarakat yang paling efektif dalam upaya mencegah morbiditas dan mortalitas.. Imunisasi juga terbukti paling cost-effective mengatasi masalah kesehatan masyarakat yang disebabkan oleh penyakit menular. Di negara-negara berpenghasilan rendah dan menengah terjadi peningkatan cakupan vaksinasi rutin selama 3 dekade terakhir, namum presentase anak melaksanakan jadwal vaksinasi yang disarankan masih di bawah target yang diharapkan $^{(3)}$. Strategisnya imunisasi sebagai alat pencegahan, menjadikan imunisasi sebagai program utama suatu negara. Bahkan merupakan salah satu alat pencegahan penyakit yang utama di dunia. Di Indonesia, imunisasi merupakan andalan program kesehatan $^{(4)}$. Imunisasi bayi dan anak dipandang sebagai perlambang kedokteran pencegahan dan pelayanan kesehatan. angka cakupan imunisasi sering dipakai sebagai indikator pencapaian pelayanan kesehatan $^{(5)}$.

Vitamin A merupakan salah satu gizi penting yang larut dalam lemak dan disimpan dalam hati, tidak dapat dibuat oleh tubuh, sehingga harus dipenuhi dari luar (essensial), berfungsi untuk penglihatan, pertumbuhan dan meningkatkan daya tahan tubuh terhadap penyakit . Hasil kajian berbagai studi menyatakan bahwa vitamin A merupakan zat gizi yang essensial bagi manusia, karena zat gizi ini sangat penting dan konsumsi makanan kita cenderung belum mencukupi dan masih rendah sehingga harus dipenuhi dari luar ${ }^{(6)}$.

Vitamin A bermanfaat untuk menurunkan angka kematian dan angka kesakitan, karena itu vitamin A dapat meningkatkan daya tahan tubuh terhadap penyakit infeksi seperti campak, diare, dan ISPA. Akibat lain yang berdampak sangat serius dari KVA adalah buta senja dan manifestasi lain dari xeropthalmia termasuk kerusakan kornea dan kebutaan ${ }^{(7)}$.

Berdasarkan latar belakang diatas dan pentingnya imunisasi dasar lengkap pada bayi balita serta manfaat dari vitamin A bagi bayi dan balita sehingga tim melakukan pegabdian masyarakat dengan judul "Penyuluhan Tentang Imunisasi Dasar, Vitamin A dan Tumbuh Kembang pada Bayi dan Balita di Wilayah Puskesmas Jenggot Kota Pekalongan"

\section{Metode}

Pengabdian yang dilaksanakan di Posyandu Jenggot Gang 5 dilakukan beberapa kegiatan berupa:

a. Penyuluhan program imunisasi dasar pada bayi dan balita

b. Penyuluhan dan pemberian vitamin A 
c. Pemantauan pertumbuhan dan perkembangan anak

Proses edukasi merupakan proses yang perlu diukur keberhasilannya, sehingga dilakukan pre dan post test menggunakan kuesioner yang ditujukan kepada ibu yang datang ke posyandu. Efektivitas proses edukasi akan dapat dilihat dari hasil pre dan post test.

Pengukuran menggunakan kuesioner yang berisi pertanyaan benar salah untuk materi imunisasi, vitamin A. untuk tumbuh kembang anak dilakukan pengukuran tunggi badan dan berat badan.

\section{Hasil dan Pembahasan}

Kegiatan pengabdian kepada masyarakat di Posyandu Jenggot Gang 5 yang dihadiri 23 orang peserta ibu yang memiliki bayi dan balita. Posyandu Jenggot Gang 5 termasuk dalam wilayah kerja Puskesmas Jenggot Kecamatan Pekalongan Selatan.

Kegiatan penyuluhan dengan memberikan materi kepada peserta tentang pentingnya imunisasi, vitamin $A$, pertumbuhan dan perkembangan anak.

Pengabdian kepada masyarakat ini dilaksanakan sesuai dengan kebutuhan dan program pemerintah dalam mengatasi kurangnya keikutsertaan imunisasi pada bayi dan balita di Wilayah Posyandu Jenggot gang 5 Kota Pekalongan.

Tabel 1 Hasil pengukuran pengetahuan ibu tentang imunisasi

\begin{tabular}{lccc}
\hline & Pre & Post & Ket \\
\hline Baik & 14 & 22 & Meningkat 35\% \\
\hline Cukup & 7 & 1 & Menurun $29,9 \%$ \\
\hline Kurang & 2 & 0 & Menurun $0,08 \%$ \\
\hline Jumlah & 23 & 23 & \\
\hline
\end{tabular}

Tabel 1 menunjukkan adanya peningkatan sebanyak $35 \%$ pengetahuan ibu tentang imunisasi dasar pada hasil evaluasi yang dilakukan.

Tabel 2 Hasil pengukuran pengetahuan ibu tentang vitamin A

\begin{tabular}{lccc}
\hline & Pre & Post & Ket \\
\hline Baik & 12 & 23 & Meningkat $48 \%$ \\
\hline Cukup & 11 & 0 & Menurun $53 \%$ \\
\hline Kurang & 0 & 0 & Tidak ada \\
\hline Jumlah & 23 & 23 & \\
\hline
\end{tabular}

Tabel 2 menunjukkan hasil pengukuran pengetahuan ibu tentang Vitamin A memiliki peningkatan yang sangat baik yaitu $48 \%$.

Pengetahuan dapat diartikan sebagai kumpulan informasi yang dapat dipahami dan diperoleh dari proses belajar selama hidup dan dapat dipergunakan sewaktu-waktu sebagai alat untuk penyesuaian diri. Pengetahuan merupakan pengenalan terhadap kenyataan, kebenaran, prinsip dan kaidah suatu objek dan merupakan hasil stimulasi informasi untuk terjadinya perubahan perilaku $^{(8)}$.

Hal ini dapat dijelaskan bahwa pengetahuan ibu - ibu yang memiliki bayi dan balita di posyandu jenggot memiliki pengetahuan baik hal ini didapatkan kenaikan pengetahuan ibu sebelum diberikan penyuluhan dan setelah dilakukan penyuluhan tentang imunisasi dasar lengkap pada bayi dan balita dan vitamin A telah mengalami peningkatan.

\section{Kesimpulan}

Kegiatan pengabdian kepada masyarakat "Penyuluhan Tentang Imunisasi Dasar, Vitamin A dan Tumbuh Kembang pada Bayi dan Balita di Wilayah Puskesmas Jenggot Kota Pekalongan" berjalan dengan baik dan berhasil meningkatkan pengetahuan ibu tentang pentingnya imunisasi dasar dan pemberian vitamin A serta merangsang keaktifan ibu untuk 
memantau tumbuh kembang anak di posyandu.

\section{Daftar Pustaka}

[1]. Ranuh IGN. Imunisasi di Indonesia, edisi 1. Satgas imunisasi Ikatan Dokter Anak Indonesia. Jakarta. 2001.

[2]. Apriyani, et al. Faktor-Faktor Yang Berhubungan Dengan Imunisasi Dasar Lengkap Pada Balita di Posyandu Wilayah Kerja Puskesmas Kampus Palembang. STIK Siti Khadijah Palembang. 2011.

[3]. Rainey, Jeanette J., et al. "Reasons related to nonvaccination and undervaccination of children in low and middle income countries: findings from a systematic review of the published literature, 1999-2009." Vaccine 29.46 (2011): 82158221.
[4]. Achmadi, Umar Fahmi. Imunisasi Mengapa Perlu?. Jakarta: PT. Kompas Media Nusantara. 2006.

[5]. Marimbi.Tumbuh Kembang, Status Gizi dan Imunisasi Dasar pada Balita. Yogyakarta : Nuha Medika. 2010.

[6]. Kemenkes. Apa Dan Mengapa Tentang Vitamin A. Jakarta. 2011.

[7]. Depkes RI. Panduan Manajemen Suplementasi Vitamin A. Jakarta. 2008.

[8]. Kumurur, V. A. Pengetahuan, Sikap dan Kepedulian Mahasiswa Pascasarjana Ilmu Lingkungan Terhadap Lingkungan Hidup Kota Jakarta. Jurnal Ekoton Vol. 8, No.2:1- 24. 2008. 